This is a self-archived version of an original article. This version may differ from the original in pagination and typographic details.

Author(s): Pankakoski, Timo; Backman, Jussi

Title: Relativism and radical conservatism

Year: 2020

Version: Accepted version (Final draft)

Copyright: (c) The contributors, 2020

Rights: In Copyright

Rights url: http://rightsstatements.org/page//nC/1.0/?language=en

Please cite the original version:

Pankakoski, T., \& Backman, J. (2020). Relativism and radical conservatism. In M. Kusch (Ed.), The Routledge Handbook of Philosophy of Relativism (pp. 219-227). Routledge.

https://doi.org/10.4324/9781351052306-24 
This is an Accepted Manuscript of a book chapter published by Routledge/CRC Press in The Routledge Handbook of Philosophy of Relativism, edited by Martin Kusch (Abingdon: Routledge, 2020), 219-27 on December 4, 2019, available online: http://www.routledge.com/9781351052306 or http://www.crcpress.com/9781351052306.

\section{Relativism and radical conservatism}

\section{Timo Pankakoski and Jussi Backman}

ABSTRACT. The chapter tackles the complex, tension-ridden, and often paradoxical relationship between relativism and conservatism. We focus particularly on radical conservatism, an early twentieth-century German movement that arguably constitutes the climax of conservatism's problematic relationship with relativism. We trace the shared genealogy of conservatism and historicism in nineteenth-century Counter-Enlightenment thought and interpret radical conservatism's ambivalent relation to relativism as reflecting this heritage. Emphasizing national particularity, historical uniqueness, and global political plurality, Carl Schmitt and Hans Freyer moved in the tradition of historicism, stopping short of full relativism. Yet they utilized relativistic elements - such as seeing irrational decisions or the demands of "life" as the basis of politics - to discredit notions of universal political morality and law, thereby underpinning their authoritarian agendas. Oswald Spengler, by contrast, took the relativistic impulses to the extreme, interweaving his conservative authoritarianism and nationalism with full-fledged epistemic, moral, and political relativism. Martin Heidegger has recently been perceived as the key philosopher of radical conservatism, and his 
thought arguably channeled antimodern aspects of historicism into contemporary political thought. We conclude by analyzing how some radical conservative arguments involving cultural relativism and plurality still reverberate in contemporary theorists such as Samuel Huntington, Aleksandr Dugin, and Alain de Benoist.

\section{Introduction}

The relationship between conservative political thought and relativism is complex and tensionridden. Many contemporary conservatives see cultural relativism as undermining communal life and, in the footsteps of Leo Strauss (1953, 9-34), point their finger at historicism (see Bloom 1987, 25, 34, 38-39), the tendency to relativize human thought and morality to their historical contexts. However, as Strauss (1953, 13-16) points out, modern conservatism and historicism have common roots in the Counter-Enlightenment's opposition to ideas underlying the French Revolution, such as natural law and universal progress. In its criticism of the unhistorical outlook of Enlightenment progressive rationalism, nineteenth-century German historicism "inevitably became a powerful ally of Conservatism" (Epstein 1966, 74). We argue that the key link between conservatism and relativism can be found in historicism.

Historicism was a predominantly German intellectual trend. Arguably, many key features of modern conservatism culminated in the German version of conservatism of the Weimar period often known as the "conservative revolution," but more comprehensively and accurately characterized as “radical conservatism” (Muller 1997; Dahl 1999). German thinkers took the intellectual developments behind classical conservatism to their "logical conclusion" (Mannheim 1925, 47), producing a radicalized, ardently antiliberal conservatism in which, we argue, conservatism's problematic relationship with relativism comes to a head.

We focus here on German radical conservatism and its shifting relationship with relativism. After mapping the common genesis of the German conservative and historicist traditions, we study relativistic aspects of twentieth-century radical conservatism and conservative aspects of Heideggerian philosophical hermeneutics, arguably the most important philosophical offspring of 
German historicism. We conclude with a brief overview of the legacy of these trends in contemporary conservative thought.

\section{Historicism and conservatism}

The roots of historicism go back to the eighteenth century. Already Giambattista Vico, often considered the father of modern philosophy of history, questioned timeless and abstract principles and emphasized the historicity of reason. Not all peoples advanced concurrently in Vico's developmental scheme of aristocracy, democracy, and monarchy; rather, governments must conform to the nature of the people governed (Vico 1744, 99, 440). Montesquieu (1748), in turn, emphasized the effects of the climate on citizens' mentality, social conventions, laws, and the form of government suitable for a given nation.

This type of political and cultural relativism was pivotal to classical conservatism's critique of the ideas of rational progress and the ideal constitution underlying the French Revolution. Chateaubriand (1797, 255, 297-298) maintained that any form of government could only be evaluated in terms of the needs of the nation and its natural constitution. Edmund Burke (1790, 27, 129) considered it "fanaticism" to regard, for example, monarchy or democracy as the only correct form of government and refused to reprobate any political form "merely upon abstract principle." Jerry Z. Muller (1997, 7, 11-12) links classical conservatism with "historical utilitarianism" according to which the merits of any societal institution are deduced from its historical survival, and with "historicism and particularism" according to which institutions are a product of human development rather than natural law or unchanging human qualities. It follows that expedient institutions vary widely across societies, eras, and traditions, and conservatism carries primarily a "procedural" emphasis on the need for institutions in general to regulate human action and keep egoistic aspirations at check, rather than a "substantive" commendation of particular institutions.

A more full-fledged form of historicism emerged within the German Enlightenment and Sturm und Drang proto-Romanticism. Friedrich Meinecke (1936, 235, 295) identifies a "new sense of history" in the late-eighteenth-century German movement represented particularly by Justus Möser, Johann Gottfried von Herder, and Johann Wolfgang von Goethe. Herder, who emphasized the historical and linguistic particularity of ideas, ranks as one of the founders of modern cultural 
relativism and philosophical hermeneutics, but was, despite his profound sense of national uniqueness, a liberal-minded believer in human progress. Möser, by contrast, combined a notion of historical particularity with a conservative theory of the reason-of-state (Meinecke 1936, 281-291) that effectively jettisoned ideas of natural law and the ideal state, positing that the state as a historical formation had an inalienable individual character and that its primary duties were to safeguard and nurture the particularity of its existence in rivalry with other states. The idea of historical individuality entailed by these approaches provided relativism with a novel theoretical basis (Meinecke 1924, 1819, 377-380; 1936, 488-489).

Isaiah Berlin (1980, 71-72, 79-80, 87) argues that neither Enlightenment nor proto-Romantic historicists advocated strict cultural or moral relativism, but rather historical pluralism. What was common to all human beings manifested itself in dissimilar, potentially conflicting, and even incommensurable ways in different historical situations, but the irreducible plurality of values did not entail a lack of foundation or standards. This form of historicism is fundamentally akin to that of Hegel, for whom different historical moral, social, and political systems were merely stages in the self-elaboration of universal objective spirit in the world - an argument that, in the conservative Right-Hegelian reading, implied that contemporary Prussia could be seen as the most developed form of Rechtsstaat. According to Berlin (1980, 77-78, 87-88), strong relativism only emerged in the nineteenth century with the antirationalism of German Romanticism, Arthur Schopenhauer, and Friedrich Nietzsche.

In the most prominent German Romantics, such as Friedrich Schlegel and Novalis, we find, in addition to a new poetic subjectivism and relativism, historicism in the form of an "organic" view of the historical growth of unique cultural formations and nostalgia for premodern, tradition-bound communities. Mannheim $(1925,47,127)$ reads Romantic organic historicism as "a product of the German conservative spirit" that initially emerged "as a political argument against the revolutionary breach with the past." Ernst Troeltsch $(1922,285)$, however, observes that when detached from its original context, the theory of cultural growth could amalgamate with either conservative or liberal politics. The politically conservative use of organic historicism is exemplified by the German historical school of jurisprudence of Friedrich Carl von Savigny and Karl Friedrich Eichhorn, which insisted, against Enlightenment ideas of natural right, that law emanated from a historically and 
culturally particular "national spirit" (Harstick 1974). Another example is Leopold von Ranke (1833/1836), the father of empiricist historicism in historiography, who opposed Hegelian teleology and the dissemination of the French revolutionary legacy through Napoleon's attempt at "universal monarchy," emphasizing the importance of organic, tradition-bound national identities.

According to Friedrich Jaeger and Jörn Rüsen (1992, 101-104), classical historicism was eventually dissolved as German idealism gave way to Lebensphilosophie: abstract life, conceived in vitalistic and quasi-biological terms, now replaced creative cultural spirit as the driving force of history. Rather than ethical, cultural, and intellectual progress, history increasingly appeared as a natural, biologically evolving life-process that underneath remained qualitatively unchanged. One can identify several steps from historicism toward the eventual affirmation of constant change, novelty, and mobilization without an ideal of ultimate teleological progress, characteristic of twentieth-century radical conservatism. These include Schopenhauer's metaphysics of the fundamentally aimless and purposeless will as the basic reality; Nietzsche's notion of truths as temporary instrumental perspectives of the eternally recurring will to power; Wilhelm Dilthey's grounding of all thought upon the continuous historical flow of lived experience; and Oswald Spengler's organic and cyclic model of history. This turn from spirit to life had obvious political implications: while classical historicism, guided by an idea of an ultimately unified humanity, still implied binding standards for states' actions, the apotheosis of life per se liberated radical nationalist politics from such bounds. Pure factual power now became a sufficient basis for political existence.

\section{Radical conservatism and relativism}

German radical conservatism was a loose intellectual movement of the Weimar era, inspired by the experiences of the world war. Rather than suggesting reactionary measures, it called for the creation of novel institutions by radical means in order to overcome the alleged egalitarian decay of modern liberal, democratic, and capitalist societies as well as the Marxist threat. It abandoned the traditional conservative postulate of "historical utility": the fact that certain institutions had survived no longer spoke in their favor (Muller 1997, 29). Radical conservatives upheld conservative ideals such as wholeness, community, or authority, but rather than seeking to conserve the old, they underlined the need to "create values worth conserving" (Moeller van den Bruck 1923, 182) - by way of a 
"conservative revolution," if needed. The key thinkers of German radical conservatism in the wide sense include Carl Schmitt, Hans Freyer, Ernst Jünger, Oswald Spengler, Martin Heidegger, Arthur Moeller van den Bruck, Edgar Julius Jung, Ludwig Klages, and Othmar Spann.

In accordance with the paradox inherent in conserving by revolutionizing, radical conservatism's relationship with relativism is complex. While rejecting liberal democracy on the grounds of its alleged link with relativism and nihilism, these authors often utilized the disruptive power inherent in historicism and relativism against any remnants of Enlightenment universalism, elevating irrational decision, life, or power per se, or seeking to ground the novel idea of community in the inherent plurality of world history. Many called for cultural and national unity and resented liberal value pluralism as "relativism." The sociologist Spann (1921, 63, 187-191) blamed the relativism inherent in the crisis of contemporary culture on individualistic social theories that allegedly led to nihilism and atomization, proposing in their stead a radically antidemocratic "universalistic" agenda relying on organic analogies. The political essayist Moeller van den Bruck (1923, 166-167) contrasted the conservative approach with the merely "relative" standpoints of liberal subjects, apparently always willing to change their views according to shallow opportunism.

Such accusations carried a grain of truth, as many contemporary liberal democrats in fact endorsed a doctrine of relativism. Hans Kelsen (1929, 101-105), for example, maintained that political stances could not be verified or refuted rationally and that relativism, combined with an open market of opinions and an electoral system based on majority rule, was therefore the optimal democratic framework. Spann (1921, 116-117) criticized Kelsen's political relativism for causing dissolution and anarchical factional struggles: liberal value relativism was a threat to political stability.

Carl Schmitt similarly rejected pluralism for shattering political unity into latent civil war and accused Kelsen's legal positivism of opening the door to relativism and nihilism (see Scheuemann 1999, 64-65). For Schmitt (1922, 10, 39-41), the pluralist chaos could not be tamed by abstract norms or inherited customs; only a sovereign decision ex nibilo, without rational justification, could secure the foundation of both law and political order. This idea is iterated in Schmitt's (1932, 26-27) concept of the political: any criterion can give rise to the political opposition between friend and enemy, and when a decision concerning the political enemy is in effect, it is instantaneous and intuitive, since the enemy is existentially alien and other. Schmitt's theory of decision and existential 
enmity has been criticized for implying the kind of nihilism he sought to avoid (Scheuerman 1999, 79), and the aforementioned aspects suggest reading him as a theorist of post-foundationalism, difference-based identities, and subjectivism - a list easy to supplement with relativism.

However, despite his radicalism, Schmitt operated within the tradition of historicist conservatism, emphasizing historical determination and particularity. In the early 1930s, he argued that key legal categories were determined by their particular national community and that all legal thought took place within "a historical, concrete, total order" (Schmitt 1934, 73). In his postwar historical work, Schmitt underscored the uniqueness of all historical truths and epochs (Lievens 2011); however, this does not imply a lack of foundations, but rather entails that singular historical events and situations are comprehensible in the context of a concrete order even when decisions lack normative foundations. Schmitt's $(1932,53)$ idea that the political world is a "pluriverse" rather than a universe is extendable into an overall theory of the global order and world history: there is always a plurality of such historically constituted units of decisions, and norms and orders are only comprehensible within their respective cultural and political spheres. Schmitt thus endorsed historical particularism and global pluralism, designed to manage the consequences of his antiuniversalistic notion of politics. This served his project of undermining liberal universalism in law and politics in favor of a "realistic" doctrine of international relations based on the equal right of states to wage wars and geopolitical segregation into several "great spaces" (Schmitt 1939-41).

Hans Freyer shared Schmitt's concept of the political, albeit with a post-Hegelian idealistic twist. Freyer saw politics as the historical implementation of cultural forms and ideas, emphasizing that the state represented a certain "unity of values" and that political deeds were necessitated by the historical moment (Freyer 1930, 105). These starting points suggest a monistic conception of the political community: for Freyer $(1930,108,113)$, the objectively good in political life was that which served the development of the people and its historical mission. In the 1930s, for Freyer, the most topical political task of the mythical and singular Volk was to destroy the structures of "the industrial society" and liberate the state from particular "interests" - that is, to replace liberal democracy with authoritarianism (1931, 44-45). In his call for a mythical revolution from the right, Freyer represented radical, even revolutionary conservatism, justified by situational political ethics. However, a plurality of such historically conditioned ideas and particularistic political units always prevailed, and pluralism 
was the essence of world history (1925, 23, 194-195, 211-212). Freyer's modified Hegelianism allowed no overarching telos, but merely the tumult of numerous consecutive empires that rose and sunk based on their factual prowess, political will, and resolution. All power was contingent, historically conditioned, and valid only once. In keeping with German historicism and reason-ofstate theory, Freyer found the basis for political order in historical particularity and cultural uniqueness.

Amongst the radical conservatives, Spengler (1918, 23-24, 46, 345, 364) took the relativistic impulse in historicism the furthest, denying eternal truths and universal morality and arguing that all standards were valid only within their respective cultural spheres. However, in his belief that the current "Faustian man" was best disposed to understand history in general, Spengler claimed universal validity for his own theory of history as cyclic and organic growth (see Falken 1988, 6667). Spengler's epistemic and moral relativism built on the postulate that human beings existed only in terms of certain epochs and regions with their particular historical horizons (Spengler 1931, 3031). For Spengler, "humankind" was a fiction incapable of possessing shared goals or living a truly universal history (Merlio 2009, 134-135). This Counter-Enlightenment stance implies a twofold political relativism: first, there were no universal ideals, truths, or justice in international relations, only factual power and effect; second, there was no single optimal form of government, but each state was unique and constantly changing (Spengler 1922, 368-370, 401). Authoritarianism or monarchism were thus not optimal forms per se, but only the most suitable ones for Germany (Spengler 1920, 71). Spengler's historicism was thus motivated by his conservative politics and extreme nationalism (Merlio 2009, 137).

\section{Heideggerian hermeneutics and conservatism}

Martin Heidegger is sometimes listed among the radical conservatives (Bourdieu 1988, 55-69; Dahl 1999, 134-135) and recently Aleksandr Dugin (2010, 23-26, 171-173) has designated Heidegger as the philosopher of the conservative revolution. In the historical narrative of the later Heidegger, the Western metaphysical tradition was currently culminating in a total technological domination and homogenization of reality, which, however, opened the possibility of a post-metaphysical, postmodern "other beginning" of Western thinking, involving a profound rethinking of the Greek 
beginning of philosophy. This idea of a cyclic movement through which nihilistic modernity was overcome by letting modernity radicalize and culminate itself, which allows us to turn back to the roots of our tradition in a novel sense, is indeed analogous to the basic model of a "conservative revolution."

Heidegger is in many ways an heir of nineteenth-century German historicism (see Barash 2003). A key objective of the hermeneutic phenomenology of Heidegger's Being and Time (1927) was to elaborate an account of the human Dasein's dynamic, context-bound, and historically singular understanding of being (Sein) in order to articulate a radically temporal and historical "fundamental ontology." This approach, which would make concepts, truths, and, ultimately, meaningfulness in general, historically situated, had obvious relativistic implications, which Heidegger accepted, noting that "fear of relativism is fear of Dasein" (Heidegger 1924, 20). In the 1930s, Heidegger's focus increasingly turned from the individual Dasein to the Volk as the basic unit of politics, and here we encounter the familiar national particularism of the conservative tradition: for an authentic community of nations to emerge, each nation must assume "responsibility for itself" by discovering its particular historical “determination” (Heidegger 1933). In 1935, Heidegger (1935, 40-41) depicted the Germans as a "historical" people caught in "pincers" between the United States and the Soviet Union - two ahistorical, multinational, and technological world powers with universalistic ideologies. However, Heidegger (1938-39, 318-319; 1941-42, 80) was soon disillusioned with Nazism, coming to see its biological racism and total warfare as just another, albeit extreme, avatar of modern technicity alongside liberalism and Bolshevism, thus revealing himself as a radical conservative rather than a committed National Socialist.

Remarkably, few of Heidegger's most prominent students were outright conservatives; some were quite the opposite, such as the Marxist and 1960s counterculture icon Herbert Marcuse. In France, the introduction of Heideggerianism through existentialism and poststructuralism coincided with a marked left-wing wave. Leo Strauss's work is often considered a key source of intellectual inspiration for American neoconservatives - but this status ultimately hinges on Strauss's relentless battle against relativism and Heideggerian "radical" historicism (Strauss 1953, 9-34; 1961, 251; Gottfried 2012, 43-57). Strauss endorsed a democracy that would not be founded on individualistic relativism, but rather on values conceived as universal and on a Platonic form of natural right. 
Precisely this made Strauss appealing to a section of the American right, but also fundamentally opposed him to the German conservative and historicist heritage. Hans-Georg Gadamer was famously accused by Jürgen Habermas $(1967,168-170)$ of ending up in Burkean-style conservatism associated with German historicism that rendered a Marxist-type critique of ideology unfeasible by insisting on the irreducible role of tradition in all understanding. In his reply, Gadamer $(1967,285)$, while defending the emancipatory potential of philosophical hermeneutics, credited conservatism with an important insight into the untenability of the Enlightenment's "abstract antithesis" between reason and the authority of the tradition.

Hannah Arendt, the most influential political theorist among Heidegger's heirs, certainly does not fit the narrow category of "conservatism." Nonetheless, her vivid interest in modern revolutions was balanced with a Roman-inspired emphasis on the political importance of authority, tradition, and preservation. She is perhaps most aptly characterized as a "reluctant modernist" (Benhabib 2003): for Arendt (1951, 305-364; 1963), modernity was at once a possibility for political refoundation and an atomizing and leveling force which dissolved local communities into a homogeneous mass society that, due to the loss of communal forms of "common sense," provided a breeding ground for totalitarian ideologies. Heidegger's influence is traceable in the latter, bleaker evaluation of modernization as a nihilistic obliteration of local differences and traditions. His philosophy has thus channeled at least some Counter-Enlightenment implications of German historicism into contemporary political thought.

\section{Contemporary repercussions: multipolarity and ethnoparticularism}

The postwar denazification of Germany weakened, but did not eradicate radical conservatism: Freyer, Schmitt, and Heidegger all published further and remained influential. In recent years, many radical conservative arguments have resurfaced in rightwing political theorizing. In particular, Francis Fukuyama's (1992) post-Cold War vision of liberal democracy as a Hegelian universal "end of history" provoked a new wave of historicist and culturally particularistic counterreactions. Among the most influential was Samuel Huntington's (1996) theory of the clash of culturally and regionally distinct "civilizations" as the dominant matrix for new geopolitics - a vision partly prefigured in Schmitt's (1939-41) model of a geopolitical ordering of "great spaces" based on different, particular 
political identities but with a degree of internal political homogeneity. Although rejecting Western universalism as "imperialism," Huntington $(1996,310-311,318)$ did not surrender to moral and cultural relativism, either - rather, he advocated the search for shared minimal moral standards amidst global cultural diversity and the recognition of the uniqueness of the West amongst other cultures.

Schmitt, Heidegger, and Huntington have inspired a new generation of conservative theorists, including, most prominently, Aleksandr Dugin and Alain de Benoist. The Russian Dugin, who has recently gained a questionable reputation as a chief ideologue of "Putinism," characterizes his recent political theory (Dugin 2009) as a "fourth" ideological alternative to the great ideologies of the twentieth century (liberalism, communism, and fascism). For Dugin, the global ideological hegemony of liberalism stemming from the "Atlantic" (Anglophone) civilization threatens the particular identities of traditionally nonliberal civilizations, such as the "Eurasian" cultural sphere dominated by Russia. Dugin's “fourth political theory” is a Schmittian and Huntingtonian multipolar geopolitical model that allows for vast differences between the major civilizational areas, each equipped with a particularistic political idea in tune with their particular traditions and ethnogenesis, yet presupposes a degree of internal cultural and political unity. While opposed to the late modern world of globalized and individualistic liberal capitalism, the fourth ideology openly exploits the relativist and historicist aspects of "postmodern" or poststructuralist thought against liberal unipolarity. Dugin (2009, 83100) explicitly proclaims himself an heir of the German conservative revolutionary movement and Heideggerian philosophy of history.

The key figure of the French New Right, de Benoist (2004, 21, 63) criticizes the Western human rights doctrine, first, for being excessively universalistic in its attempt to govern the particular by abstract principles; second, for being subjectivistic in that it defines rights in terms of individuals and thus leads to relativism; and third, for absolutizing historically particular ideas into timeless truths and for imperialistically imposing the values of one culture upon others. However, he denies that this rejection of universal human rights would itself entail relativism, rather endorsing the "pluralist position" that humanity "presents incompatible value systems" (Benoist 1985, 99; 2004, 78). Every human being is equally a member of humankind, but this membership is "always mediated by a particular cultural belonging" (Benoist and Champetier 1999, 123). The pragmatic political corollary of this view is the doctrine of "differentialist ethnopluralism" or "ethnoregionalism": universalist 
“imperialism" must be rejected, each culture should stay confined to its geographical area, and Western Europe, too, has the right and duty to protect its cultural heritage (Spektorowski 2003). While traditional conservatism used pluralism to underpin traditional state-driven nationalism, here ethnopluralism is raised against liberal multiculturalism, in order to justify exclusionary political practices.

Despite its complexity, the alliance between relativism and political conservatism has proved surprisingly enduring. The Counter-Enlightenment counternarrative of irreducible differences between cultures and epochs and the concomitant idea of history as nonteleological change has coexisted with the Enlightenment narrative of the universal progress of humanity in one form or other for more than two centuries. Contrary to a common conception, neither narrative shows genuine signs of abating - on the contrary, both have recently been reaffirmed, with Steven Pinker (2018) as the most prominent recent herald of the latter, and may well continue to configure the ideological parameters of the future for an indefinite time.

\section{References}

Arendt, H. (1951), The Origins of Totalitarianism, second edition, San Diego: Harcourt Brace \& Co, 1979.

—. (1963), On Revolution, London: Penguin Books, 1990.

Barash, J. A. (2003), Martin Heidegger and the Problem of Historical Meaning, second edition, New York: Fordham University Press.

Benhabib, S. (2003), The Reluctant Modernism of Hannah Arendt, second edition, Lanham, MD: Rowman \& Littlefield.

Benoist, A. de (1985), The Problem of Democracy, translated by S. Knipe, London: Arktos, 2011. . (2004), Beyond Human Rights: Defending Freedoms, translated by A. Jacob, London: Arktos, 2011.

Benoist, A. de and C. Champetier (1999), “The French New Right in the Year 2000," Telos no. 115: 117-144. 
Berlin, I. (1980), “Alleged Relativism in Eighteenth-Century European Thought," in his The Crooked Timber of Humanity: Chapters in the History of Ideas, edited by H. Hardy, London: Murray, 1990, 70-90.

Bloom, A. (1987), The Closing of the American Mind: How Higher Education Has Failed Democracy and Impoverished the Souls of Today's Students, New York: Simon \& Schuster.

Bourdieu, P. (1988), The Political Ontology of Martin Heidegger, translated by P. Collier, Stanford, CA: Stanford University Press, 1991.

Burke, E. (1790), "Reflections on the Revolution in France," in his Revolutionary Writings, edited by I. Hampsher-Monk, Cambridge: Cambridge University Press, 2014, 1-250.

Chateaubriand, F.-R. de (1797), An Historical, Political, and Moral Essay on Revolutions, Ancient and Modern, London: Colburn, 1815.

Dahl, G. (1999), Radical Conservatism and the Future of Politics, London: Sage Publications.

Dugin, A. (2009), The Fourth Political Theory, translated by M. Sleboda and M. Millerman, London: Arktos, 2012.

- (2010), Martin Heidegger: The Philosophy of Another Beginning, translated by N. Kouprianova, Arlington, VA: Radix, 2014.

Epstein, K. (1966), The Genesis of German Conservatism, Princeton, NJ: Princeton University Press.

Falken, D. (1988), Oswald Spengler: Konservativer Denker zwischen Kaisserreich und Diktatur, Munich: Beck. Freyer, H. (1925), Der Staat, Leipzig: Rechfelden.

—. (1930), "Ethische Normen und Politik," Kant-Studien 35: 99-114. . (1931), Revolution von Rechts, Jena: Diederichs.

Fukuyama, F. (1992), The End of History and the Last Man, New York: Free Press.

Gadamer, H.-G. (1967), "Rhetoric, Hermeneutics, and the Critique of Ideology: Metacritical Comments on Truth and Method," translated by J. Dibble, in The Hermeneutics Reader, edited by K. Mueller-Volmer, New York: Continuum, 1985, 274-292.

Gottfried, P. E. (2012), Leo Strauss and the Conservative Movement in America: A Critical Appraisal, Cambridge: Cambridge University Press.

Habermas, J. (1967), On the Logic of the Social Sciences, translated by S. Weber Nicholsen and J. A. Stark, Cambridge, MA: MIT Press, 1988. 
Harstick, H.-P. (1974), “Historische Schule," in Historisches Wörterbuch der Philosophie, vol. 3, edited by J. Ritter, Basel: Schwabe, 1137-1141.

Heidegger, M. (1924), The Concept of Time, translated by W. McNeill, Oxford: Wiley-Blackwell, 1992. . (1927), Being and Time, translated by J. Stambaugh, translation revised by D. Schmidt, Albany, NY: State University of New York Press, 2010.

—. (1933), “German Men and Women!” translated by W. S. Lewis, in The Heidegger Controversy: A Critical Reader, edited by R. Wolin, Cambridge, MA: MIT Press, 1993, 47-49.

. (1935), Introduction to Metaphysics, translated by G. Fried and R. Polt, New Haven, CT: Yale University Press, 2000.

. (1938-39), Ponderings VII-XI: Black Notebooks 1938-1939, translated by R. Rojcewicz, Bloomington, IN: Indiana University Press, 2017.

. (1941-42), The Event, translated by R. Rojcewicz, Bloomington, IN: Indiana University Press, 2013.

Huntington, S. P. (1996), The Clash of Civilizations and the Remaking of World Order, New York: Simon \& Schuster.

Jaeger, F. and J. Rüsen (1992), Geschichte des Historismus: Eine Einführung, Munich: Beck.

Kelsen, H. (1929), The Essence and V alue of Democracy, edited by N. Urbinati and C. Invernizzi Accetti, translated by B. Graf, Lanham, MD: Rowman \& Littlefield, 2013.

Lievens, M. (2011), "Singularity and Repetition in Carl Schmitt's Vision of History," Journal of the Philosophy of History 5: 105-129.

Mannheim, K. (1925), Conservatism: A Contribution to the Sociology of Knowledge, edited by D. Kettler, V. Meja, and N. Stehr, translated by D. Kettler and V. Meja, Abingdon: Routledge, 2007.

Meinecke, F. (1924), Machiavellism: The Doctrine of Raison d'État and Its Place in Modern History, translated by D. Scott, New Haven, CT: Yale University Press, 1962.

- (1936), Historism: The Rise of a New Historical Outlook, translated by J. E. Anderson, London: Routledge \& Kegan Paul, 1972.

Merlio, G. (2009), "Spenglers Geschichtsmorphologie im Kontext des Historismus und seiner Krisen," in Spengler: Ein Denker der Zeitenwende, edited by M. Gangl, G. Merlio, and M. Ophälders, Frankfurt am Main: Lang, 129-143. 
Moeller van den Bruck, A. (1923), Germany's Third Empire, translated by E. O. Lorimer, London: Arktos, 2012.

Montesquieu, C.-L. de Secondat de (1748), The Spirit of the Laws, translated by A. M. Cohler, B. C. Miller and H. S. Stone, Cambridge: Cambridge University Press, 2008.

Muller, J. Z. (1997), “Introduction: What Is Conservative Social and Political Thought?” in Conservatism: An Anthology of Social and Political Thought from David Hume to the Present, edited by J. Z. Muller, Princeton, NJ: Princeton University Press, 3-31.

Pinker, S. (2018), Enlightenment Now: The Case for Reason, Science, Humanism, and Progress, New York: Penguin.

Ranke, L. von (1833/1836), “A Dialogue on Politics; The Great Powers,” translated by T. Hunt von Laue and H. Hunt von Laue, in Leopold Ranke: The Formative Years, edited by T. Hunt von Laue, Princeton, NJ: Princeton University Press, 1950, 152-218.

Scheuerman, W. E. (1999), Carl Schmitt: The End of Law, Lanham, MD: Rowman \& Littlefield.

Schmitt, C. (1922), Political Theology: Four Chapters on the Concept of Sovereignty, translated by G. Schwab, Chicago: University of Chicago Press, 2005.

. (1932), The Concept of the Political, second edition, translated by G. Schwab, Chicago: University of Chicago Press, 2007.

(1934), On the Three Types of Juristic Thought, translated by J. W. Bendersky, Westport, CT: Praeger, 2004.

- (1939-41), "The Großraum Order of International Law with a Ban on Intervention for Spatially Foreign Powers: A Contribution to the Concept of Reich in International Law," in his Writings on War, translated and edited by T. Nunan, Cambridge: Polity Press, 2011, 75124.

Spann, O. (1921), Der wahre Staat: Vorlesungen über Abbruch und Neubau der Gesellschaft, Leipzig: Quelle \& Meyer.

Spektorowski, A. (2003), “The New Right: Ethno-Regionalism, Ethno-Pluralism and the Emergence of a Neo-Fascist 'Third Way," Journal of Political Ideologies 8(1): 111-130.

Spengler, O. (1918), The Decline of the West, Volume 1: Form and Actuality, translated by C. F. Atkinson, New York: Knopf, 1927. 
. (1920), "Prussianism and Socialism," in his Selected Essays, edited and translated by D. O. White, Chicago: Regnery, 1967, 1-131.

- (1922), The Decline of the West, Volume 2: Perspectives of World-History, translated by C. F. Atkinson, New York: Knopf, 1928.

- (1931), Man and Technics: A Contribution to a Philosophy of Life, translated by C. F. Atkinson and M. Putman, London: Arktos, 2015.

Strauss, L. (1953), Natural Right and History, Chicago: University of Chicago Press, 1965.

- (1961), On Tyranny, second edition, edited by V. Gourevitch and M. S. Roth, Chicago: University of Chicago Press, 1991.

Troeltsch, E. (1922), Gesammelte Werke, Volume 3: Der Historismus und seine Probleme, Volume 1: Das logische Problem der Geschichtsphilosophie, Tübingen: Mohr.

Vico, G. (1744), New Science: Principles of the New Science Concerning the Common Nature of Nations, third edition, translated by D. Marsh, London: Penguin, 2001. 